Agnieszka Zemke-Górecka

\title{
THE REFORMS OF FINANCING THE SYSTEM OF HEALTH PROTECTION IN POLAND
}

\section{Introduction}

According to the WHO's report, the concept of the health system (called the system of health protection) comprises by its scope all organizations, institutions and resources that are intended for health activities ${ }^{1}$. The health system in Poland covers a group of institutions whose aim is to organize, finance and, most of all, provide health services and promote health. After the World War II the system of health protection in Poland was based on the Beveridge's model, the so called procurement model, which was called health service. As a result of the reforms carried out in the last decade in Poland we are dealing with a mixed model of financing health services. On the one hand the Bismarck model is binding, which is the so called insurance model based on a premium paid by an insured person or the state budget, and on the other hand, a certain scope of health services (highly specialized) is financed by the state budget. Since 1999 the health care has been supported from several sources of finance. The largest revenue thereof come from health insurance premiums which are collected by the National Health Fund. The state budget is the second largest source of public finance followed by the budgets of local self-government units whose income comes from taxes and local charges, state budget transfers and outof-budget target funds, and, to a certain minor extent, from social organizations' resources, e.g. foundations which supply the system of health care with financial means. Incomes of households, working places funds, private health insurance funds and charitable organizations' funds play an important role among private sources of financing health care ${ }^{2}$. A problem of financial resources is a key element of all and any considerations connected with the health care reform. 


\section{The structure of the health system and its finance in 1945-1989}

After the World War II a socialist system of health service started to be introduced. Already in 1944 it was announced in PKWN's manifesto (the Polish Committee of National Liberation) that it was absolutely necessary to provide working masses with medical care. After the War the State played a role of a sole organizer of health care. In effect, all units of health care as well as pharmacies were nationalized, and medical workers' self-government was liquidated. In 1952 labor health care was incorporated in the state health service administration ${ }^{3}$ and since then the state budget financed health care from general taxes and other budget incomes. In the light of the provision of Art. 60 of the Constitution of $1952^{4}$ the State was obliged to undertake any actions in order to prevent illnesses and provide help in the event of illness.

A centralized character of the state authority and liquidation of local selfgovernment had a negative effect on health care functioning in Poland. Formed structures of health care derived means for their operation from the state budget. Financial management in health service was based on the so called section-bysection plan of the national planned economy system. Budgets of social institutions of health service and other budgets in the scope of health care and illness prevention were worked out and established centrally. In collaboration with competent ministers, the Minister of Health made a project of financing a detailed economic plan in the scope of health service indicating appropriate financial plans which were to cover the expenditure (state budget, local self-governments' budgets, social insurance institutions' budgets, units' own resources coming from charges paid by people who were using the units' services, etc.). The Budget Act centrally determined allocation of resources into individual provinces and departments. For fifty years health care finance was based on the so called subjective system, which is also called a procurement system. In this system the costs of a health service unit's support were financed. The level of the state budget donation had nothing in common with the costs estimation carried out on the basis of a size, structure and quality of performed services because it depended on the expenses born in a previous budget year by the unit. Therefore, it was not a number of performed tasks that decided about the level of finance but administrative, medical and any other needs demonstrated by a health service unit. The State financed investment tasks, including the purchase of equipment and medical devices for hospitals and surgeries. This system was anti-motivational in its nature. Moreover, the Act on Social Units of Health Service Administration of Health Service, Journal of Laws - Dz. U., No. 67, item 446.

4 The Constitution of the People's Republic of Poland, Journal of Laws - Dz. U. of 1952 No. 33, item 232. 
specified that if the institutions supporting social units of health service would have to bear expenses connected with the performance of tasks resulting from the realization of health service provisions which exceed their financial capacity, they receive appropriate support from the State Treasury in a form of credits envisaged for this purpose in the budget. The rules on providing local self-governments with support were set forth on the basis of Art. 4 (2) of the $9^{\text {th }}$ March 1948 Act on SelfGovernment Compensating Fund ${ }^{5}$, whereas Minister of Health established it with reference to other institutions in collaboration with the Secretary of the Treasury.

A post-war system of health care presumed patients' co-payment for services they were provided with. The rules on making payments were regulated by the Act of $7^{\text {th }}$ April, 1949 on Covering Charges in Hospitals Being Health Service Social Units $^{6}$. This Act set forth that patients paid charges for treatment if special provisions did not specify otherwise. The Act regulated the issue of payment for treatment by specifying rates of subsidies, which were dependent on established income thresholds. It regarded medical treatment of patients who permanently lacked sufficient means to satisfy the necessities of life and due to their age or health condition were fully unemployable or unfit to work to an extent which prevented them from satisfying the necessities, as well as the patients who temporarily lacked sufficient means to satisfy the necessities of life due to temporary inability to be employed; the charges were paid by people who were obliged to pay alimony under civil law. In the event of the lack of subjects obliged to make payment, it was covered by poviat self-government and urban and rural municipalities where the patient was entitled to social welfare by virtue of the Act of $16^{\text {th }}$ August, 1923 on Social Welfare ${ }^{7}$. Moreover, it was established that the municipality of the capital city of Warsaw and of the city of Łódź as well as urban municipalities of subdivided cities cover payments in full whereas urban municipalities of non-subdivided cities and rural municipalities cover $30 \%$ of due payments for medical treatment, the remaining $70 \%$ was paid by local poviat selfgovernments that were territorially competent for those municipalities. In the case of people who were not entitled to social welfare in any municipality, the charges were paid by the State Treasury. Persons running agricultural farms who did not possess any property that was subject to a real estate tax and who did not obtain any income and did not perform any additional activities that were subject to business or income tax were exempted from hospital charges provided the estimated revenue on their farm did not exceed $10 \mathrm{q}$ annually. If farmers had to be treated in hospitals where higher charges for treatment than those in poviat hospitals were established, the State Treasury was burdened with the obligation to subsidize a full rate of higher charges. Ministers of Public Administration and Health could grant reductions /allowances 
for hospital charges in a form of a regulation in collaboration with the Secretary of the Treasury and competent ministers and with the State Council's consent, for sea fishermen and craftsmen and their families within the entire territory of Poland or those areas where it was economically justified, as well as specify the terms of awarding allowances, their rates for individual hospitals and areas where they were going to be applied as well as the rules of subsidies coverage. The State Treasury covered hospital charges for people entitled to medical treatment at the cost of the State Treasury under special provisions (e.g. those who were subject to mandatory treatment in the case of infectious or venereal diseases unless they were entitled to medical support on the basis of provisions on social insurances). The people covered by social insurance under the Act of $28^{\text {th }}$ March, 1933 on Social Insurance ${ }^{8}$ did not pay for medical treatment. In 1976 as a result of the amendment of Art. 70 of the Constitution, a rule of free medical help for all employees and their families was introduced. As the catalogue of persons entitled to free medical treatment within social insurance expanded, at the beginning of the 1990s almost all citizens were covered by health care, and even though the provisions concerning payment for medical treatment were repealed only in 1997, they became a dead letter much earlier. The establishment of sector rules of health care for individual professional groups (uniformed services as well as Polish National Railway employees enjoyed health care on completely different rules than other citizens) was a characteristic element of post-war health care.

\section{Institutional and organizational changes of the health system after 1989}

In 1989, together with the political system transformation in Poland, a debate on health care reform started. The need to undertake works on the change of the existing rules of health care for citizens arose as a result of the system's insufficiency as well as increasing expenditure thereon which did not bring expected results. The Polish Round Table's settlements were not detailed enough to create a certain foundation of objectives and perspectives of the health system in Poland. Therefore, a debate on health care reform started. At that time two projects of health care reform were established: social ${ }^{9}$ and proprietary ${ }^{10}$. The first one presumed a declaration of support for a certain system of values where patient's and health care worker's subjectivity was of crucial importance ${ }^{11}$. According to it, a patient had a right to choose

8 Journal of Laws - Dz. U. of 1933 No. 51, item 396.

9 The project of the reform of the system of health care, MZiOS Warsaw 1989.

10 W interesie zdrowia społeczeństwa (The project of the reform of the system of health care), Biuletyn Instytutu Gospodarki Narodowej 1990.

11 W. C. Włodarczyk: Reforma opieki zdrowotnej w Polsce, Kraków 1988, p. 171. 
a physician and a health care unit. At the same time it was s/he who was supposed to be a medium/carrier of financial means connected with his medical treatment. The social project envisaged the appointment of Health Insurance Fund which would have been based on a health insurance premium. The Fund's objective was to cover health services costs. A possibility of introducing a minimum lump-sum payment that was to be collected from a patient was also taken into consideration. The proprietary project envisaged the introduction of common health insurances whereas the State's financial share in the costs of health care was to be limited, e.g. with reference to specific health programs.

The Act of 1991 on Health Care Institutions (the Act on HCI), which broke off with a former concept of the national and social health service and introduced a new nomenclature: public institutions of health care, was of an essential importance for developing a new health system. The subject legal act severed a sole monopoly of the State on running health care institutions. Since the Act was passed on, public health service has been able to function in three forms: as a budget unit, a budget entity or a public independent health care institution. The Act on HCI was a breakthrough in the principles of operation of budget units and entities specified by the budget $\mathrm{law}^{12}$. In contrast to other budget units and entities, health care institutions could keep at their disposal $70 \%$ of budget resources that were not used in a given year if they were run in a form of a budget entity, and $70 \%$ of the payment intended for the budget if they were run in a form of a budget unit or other form of out-of-budget management.

\section{A change of the model of financing health services into health insurance}

In 1994 several meetings with representatives of various parliamentary and non-parliamentary groups and representatives of trade self-governments, trade unions and invited experts were held. The so called documents from Jachranka were drawn up, which recommended the acceptance of the Insurance Act awarding rights to health services and assuring equal access to them. Those services were divided into those which should be provided for by public means and other which should be paid for. Therefore, premiums were to become a basic source of finance. Moreover, another document called "Strategy for Health" ${ }^{13}$ was created, which formulated four objectives concerning the improvement of society's health, assurance of common access to health services and equal rights as to the scope and quality of health care, an

The Act of $5^{\text {th }}$ January, 1991 Budget Law, uniform text: Journal of Laws - Dz. U. of 1993 No. 72, item 344 with amendments

13 Strategia dla zdrowia, Antidotum 1994, No. $9-10$, p. 3. 
increase of health care system's efficiency and improvement of quality of provided services as well as assurance of appropriate sources of their financing.

In December 1994 the presumptions of a new legal act were presented, which was to replace a procurement system of health care with a health insurance system financed by premiums. It was to be common and obligatory, demonstrate social solidarity, provide the State guarantees for citizens' health safety, provide contracts for health services under market rules through common health insurance funds. They were to provide self-financing of health services except for institutions' investment expenses, medical staff education and improvement, and financing didactic and scientific research activity.

A catalyst of changes connected with health services financing was the Act of $6^{\text {th }}$ February, 1997 on Common Health Insurance ${ }^{14}$, which specified vacatio legis for nearly two years. The aim of this Act was, most of all, a transfer from the budget system of health care financing into an insurance one. It should be emphasized that the first version of health insurance did not come into force due to the Cabinet change (after 1997 election) an extensive amendment was issued, which introduced a regional division of Health Care Funds. Common health insurance was based on general principles such as social solidarity, self-government, self-financing, equal access to services, economical management and purposefulness of action, the right to a free choice of a service provider and a Health Care Fund, and non-profit activity of Health Care Funds. The Act determined the collection of premiums from people who were subject to mandatory insurance, which were intended for the provision of periodic health services.

Under the Insurance Act, 16 regional Health Care Funds were appointed as well as the Uniformed Services Health Care Fund. The Health Care Fund was to be a self-governing institution representing the insured. The independence of Health Care Funds was of a double dimension, namely, the autonomy of organizational self-formation and independent action within the frames of an entrusted function of a remitter. According to general principles of the constitutional order, basic functions of coordination and protection in the scope of health protection belonged to legislative and executive authorities. In order to protect the insured's interests the Health Insurance Supervision Office was appointed, whose aim was to control Health Care Funds as well as service providers to a certain extent.

It should be emphasized that before the Act on Common Health Insurance was introduced, in 1998 a provision on the State's responsibility in the scope of execution of the provision of Art. 68 of the Constitution was removed. In connection with this, the problem concerning a legal status of Health Care Funds arose. Initially, according 
to the prevailing tendency, the Health Care Fund was neither a state organization entity ${ }^{15}$ nor a public administration body ${ }^{16}$, and the resources at its disposal were not public resources. It was very comfortable for administrators of these resources because no one had to justify the way of they were managed, moreover, it was easier to make corrections and withdraw from erroneous decisions. Only the amendment, made in 2000, of the Act of $26^{\text {th }}$ November, 1998 on Public Finance ${ }^{17}$ clearly specified that Health Care Funds, the Polish National Association of Health Care Funds and public independent health care institutions belonged to the public finance sector. The health insurance premium is a specific parameter of the health protection system. The mechanism of premiums' calculation is very complicated and is carried out in a dynamically changing economic environment. An increase of health protection being financed from the premium occurs together with a decrease of financing from the state budget. The expenditure of the local self-government units in the area of health protection comprises three kinds of activities: health protection, public health and social welfare. After the introduction of the health insurance system, poviats and self-government provinces became burdened with the biggest responsibility for the fulfillment of tasks in the area of health protection, which results from the fact that they perform a function of founding bodies for health care institutions.

The presumptions of the reform of financing health protection system of 1997 distinguished four stages:

Stage I - until the end of 1998 - health care institutions were to become independent; building Health Care Funds' structures and carrying out an operation of health services contracting for 1999;

Stage II - until the end of 1999 - a computer system of Health Care Funds as well as monitoring and settlement of health services were to be developed, the application of productivity measure and standardized principles of costs evaluation were to be implemented, accreditation of health care institutions was to be disseminated, standardized principles of medical services quality control were to be applied, health care institutions' offers were to become competitive;

Stage III - until the end of 2001 - this stage was to strengthen the system leading to a common application of productivity measure and standardized principles of costs evaluation as well as prepare common health insurance to the conditions of insurance institutions' competitiveness;

15 The Supreme Court's resolution of $27^{\text {th }}$ April, 2001, OSNC 2001, No. 11, item 161.

16 The Supreme Court's decision of $17^{\text {th }}$ November, 2001, OSNAP 2001, No. 14, item 473.

17 Journal of Laws - Dz. U. of 2000 No. 48, item 550. 
Stage IV - since $1^{\text {st }}$ January 2002, the health insurance market was to open together with a possibility of realizing health insurance obligation in other institutions than the Health Care Fund.

The fact that the Act on Common Health Insurance came into force on $1^{\text {st }}$ January, 1999 meant the acceptance of a new health system model based on the so called insurance system that derived from the tradition of the classic Bismarck model of financing health services connected with the risk of a loss of health, where financial resources coming from the premiums paid in different proportions by an employee and an employer are gathered in the Health Care Funds - institutions independent of public administration. This Act distinguished a function of a remitter and a service provider whereas the system-internal bonds were based on the service agreement for the provision of health services. Health Care Funds and the Ministry of Health played a role of a remitter, moreover, self-governments could grant orders for health services. As a centralized public fund the state budget serves the purpose of money collection in connection with the functions realized by the State ${ }^{18}$. Since 1999, in Poland, highly specialized medical procedures, health programs, first aid service, public blood service and sanitary inspection have been financed from the state budget. Some of those expenses are transferable in nature because a part of health insurance premiums of the people who do not obtain income is financed from the state budget.

\section{A new version of health insurance}

It turned out that the next stage of the reforms would not proceed in accordance with earlier presumptions. In 2001-2002 the Cabinet decided that it was necessary to break off with the past and lead to the Health Care Funds' liquidation, which should be replaced with the National Health Fund. This institution was founded by virtue of the Act of $23^{\text {rd }}$ January, 2003 on Common Health Insurance in the National Health Fund ${ }^{19}$.

The National Health Fund was appointed to repair the system of health protection in Poland. Previous Health Care Funds were transformed into one Polish national fund with headquarters in Warsaw and with 16 provincial branches; the Uniformed Services Health Care Funds were replaced by the Department for Uniformed Services included in the National Health Fund's head office represented by departments for uniformed services in individual branches. Under the Act patients

\footnotetext{
18 S. Owsiak, Finanse publiczne. Teoria i praktyka, Warsaw 2005, p. 102 and next, as well as K. Piotrowska Marczak, Obciążenia finansów publicznych z perspektywy ochrony zdrowia, [in]: W kręgu prawa finansowego i finansów publicznych, Księga dedykowana profesorowi Cezaremu Kosikowskiemu w 40 - lecie pracy naukowej, Lublin 2005, p. 293 - 300; Journal of Laws - Dz. U. of 2003 No. 45, item 349.
} 
insured in the Health Care Funds automatically retained a status of the insured in the National Health Fund. According to the propaganda-oriented assumption, a uniform fund was to be a more effective solution than previous Health Care Funds. The National Health Fund took over a function of a remitter in the system of financing health services from the Health Care Funds. It became a sole administrator of health insurance premiums transferred through ZUS (National Insurance Agency) and KRUS (Farmers' Social Security Fund), and therefore it remained a monopolist awarding contracts for medical and health services for the subjects executing them. However, it failed to influence standardization/unification of rates.

\section{The system of common health insurance after the Constitutional Tribunal's judgment K. 14/03}

The legal regulations included in the Act on Common Health Insurance in the National Health Fund arose social dissatisfaction, which led to a submission of constitutional complaints. The objection raised at that time concerned the fact that the Act had not introduced any, even intermediary, possibility of a control over public money expenditure to be exerted by the insured. Health insurance premium was treated as a public tribute/levy equal to payment in its nature, which was inconsistent with the essence of health insurance being of an insurance nature. The applicants called the public means obtained from the insurance out-of-budget target fund. They stressed that depriving citizens of the right to control the money coming from the premium violated the so called rule of the acquired/vested rights protection resulting from Art. 2 of the Constitution. The Act on the National Health Fund made the Fund entirely dependent on Minister of Health. By virtue of the judgment of $7^{\text {th }}$ January, 2004, K 14/0320 , the Constitutional Tribunal ruled that Art. 36 (1) of the Act of $23^{\text {rd }}$ January, 2003 on Common Health Insurance in the National Health Fund in connection with the provisions therein concerning the National Health Fund's organization and rules of action (Chapter 1 and 4), principles of securing health needs and organization of health services provision (Chapters 5, 6, 7 and 8), finance management (Chapter 9), principles of supervision and control of performing tasks by the National Health Fund (Chapter 13) were inconsistent with Art. 68 in connection with Art. 2 of the Constitution of the Republic of Poland "because by creating a public institution in a shape that prevents its reliable and efficient action, they violate the rule of law in the state in the scope of citizens' constitutional right to equal access to health care services financed from public resources" ${ }^{21}$. The above mentioned provisions, and practically speaking almost the entire Act, would have

The Constitutional Tribunal's Judgment of $7^{\text {th }}$ January, $2004 \mathrm{~K}$ 14/03, OTK ZU 2004, No. 1A, item 1.

The Constitutional Tribunal ruled that a legal structure of the National Health Fund cannot be classified under any legal structure as a whole. 
become null and void as of $31^{\text {st }}$ December, 2004. The Constitutional Tribunal's judgment acknowledging the inconsistence of the Act on Common Health Insurance in the National Health Fund with the Constitution effected in the need to work out a new comprehensive regulation specifying terms and scope of using health care by citizens.

On $27^{\text {th }}$ August 2004 the Act on Health Care Services Financed from Public Resources was passed ${ }^{22}$. This legal act was created on the so called fast legislative track. The above mentioned Act refers to the insurance model of health protection. However, it arises numerous objections. Modifying the insurance system, the legislator included in its scope administrative mechanisms (which are grossly inconsistent with an obligation-type nature of a legal relationship) which should be based on the subjects' autonomy, the freedom of choice and the freedom of agreements $^{23}$. This Act is a result of political conditions connected with the need to retain health insurance structure due to limited resources of financial means that can be designated for health protection, whereas at the same time this model became entangled in a system of dependencies originating from administrative law, where government administration plays a leading role, where basic management instruments are: decision, official order and supervision. Moreover, the Act includes numerous incoherencies and fails to specify tasks and ensuing responsibility in a precise way.

\section{Conclusions}

The system, organized in 1948, functioned in an unchanged form until the beginning of the political system transformation in Poland. Alternatively, patients paid partially for medicines. According to estimations, expenditure born by households on health care amounted then to $12-14 \%$ of all source of financing ${ }^{24}$. It should be emphasized that pursuant to Art. 70 of the previously binding Constitution citizens were entitled to the right to use free health service. A transformation from the budget-insurance-self-government system that existed in the 1940s to the budget system in the 1970s was smoothly carried out thanks to the fact that more and more people were covered by social insurance.

The first signs of the crisis in budgeting health service appeared in the middle of the 1980s. A basic cause of disintegration of that system of health care was undeniably too expanded infrastructure of health service units. It was evident that

Journal of Laws - Dz. U. No. 213, item 2161.

J. Jończyk, Czwarta wersja powszechnego ubezpieczenia zdrowotnego, PiZS 2004, No. 11, p. 3.

A. Windak, Podstawowa opieka zdrowotna, stan obecny i perspektywy reform w Polsce, in: collective work edited by S. Poździoch and A. Ryś, Zdrowie publiczne. Wybrane zagadnienia. Kraków 1996, p. 282. 
rational management of their resources did not exist. In Poland thee was no need then to integrate the health care system functioning within 49 provinces into one framework which could supplement medical facilities shortages in one province with another province's infrastructure. There were situations, before 1990, where unequal division of resources flowing from the state budget for health protection resulted in the excessive development of infrastructure in some provinces (most frequently the most industrialized ones) and negligence in others.

In conclusion, there was the state monopoly on health service in the postwar Poland until 1999. Fr many years health service was made to be seen as ideal in the Polish system by strengthening beliefs in free health care; as a possibility of satisfying all needs and the absolute role of the State as both an organizer and a remitter of health services. It was possible to look at the state monopoly from two perspectives, namely:

- the monopoly of financing health service by the expenses from the state budget;

- the monopoly of health protection organization in a form of public units of health care.

Main features of financing health care by the state are: "zero price for the patient at the moment a service is bought, a lack of direct interdependence between the amount of taxes paid by a patient and a number of health services he or she purchases, the surplus of demand over supply of health services results in waiting long for medical services and the need to ration them out". This model envisages that a main source of financing is the state budget which is integrated regionally because the sources of financing remain at the disposal of a local administrator of health care, e.g. a provincial physician who concludes contracts with health care units $^{25}$.

In 1999-2004 the health protection reform was carried out at the level of service providers and a remitter of medical services. The foundation for transformations in the health system was separation of a body which establishes a unit (i.e. the owner) from the administrator of financial means. The transformation of budget entities' structures into independent institutions occurred, the privatization of services was introduced, family doctors practices and group practices of specialist doctors were established on a scale that had not been seen before. The second level of changes concerned a sphere of financing new subjects with the help of contracts that replaced a previous budget financing. Government administration continued to play a role of a remitter only in the scope of highly specialized health services. 
Local self-government units are obliged to finance health services within the frames of prophylactic health programs. Pursuant to the Act on Work Medicine Service ${ }^{26}$ employers provide employees with specified health services therein. What is more, insurance companies were created, which within life insurance or commercial health insurance buy out health insurances insuring their clients outside the system of health insurance. A reasonable system of health care should guarantee a limited package of high quality benefits for everyone and at the same time enables a voluntary health insurance for those who cannot afford it $>$ With reference to other people, clearly specified rules of providing health services should be laid down and the criteria of availability should be pointed out.

Valid legislation introduces a mixed system of public financing of health services independent of the patient's admissible share. Apart from the institutions appointed solely to such finance in a form of Health Care Funds - now NFZ (National Health Fund), acting on the basis of the premium paid by the insured, some health services are paid directly from the state budget. These are mainly highly specialized services. Moreover, there are also services connected with infectious diseases and withdrawal treatment ( 24 hour institutions of withdrawal treatment are to be organized by the province council whereas the other - by the Starost office). Financing health protection in Poland appears to be quite distinct depending whether a medical services provider belongs to the public or non-public sphere. With regard to public entities unfavorable polarization of financing sources can be noticed as opposed to diversification of non-public sector's revenues ${ }^{27}$. In Poland public funds are a very varied group of sources of financing health care services, the greatest role being now played by the central target fund - the National Health $\mathrm{Fund}^{28}$. A health insurance premium is an instrument to obtain revenue by the Fund. Another important public source is the state budget as well as local self-government units' budget, whereas out-of-budget target funds, e.g. Labour Fund, play a certain role in financing health care as well ${ }^{29}$. A share of private funds is increasing, and not only those coming from households but also those coming from employers' funds through the so called medical subscriptions. In the solution introduced by the Act of $6^{\text {th }}$ February, 1997 on Common Health Insurance as well as solutions introduced by the Act of $23^{\text {rd }}$ January, 2003 on Common Health Insurance in the National Health Fund "a common insurer - and strictly speaking a premium in this insurance, was joined with natural persons' income tax. Hence, this kind of approach refers to the tradition of health insurance as social insurance and presumes commonness of personal income tax ${ }^{30}$ ". J. Sobiech assumes that due to that fact health insurance cannot be considered common since

\footnotetext{
26 Uniform text: Journal of Laws - Dz. U. of 2004 No. 125, item 1317.

27 A. Sieńko, Prawo ochrony zdrowia, Warsaw 2006, p. 74

28 J. Rój, J. Sobiech, Zarządzanie finansami szpitala, Warsaw 2006, p. 38.

29 Ibidem

$30 \quad$ Ibidem, p. 39
} 
it depends on employment. Premiums for health insurance are collected by ZUS and KRUS whereas revenues on premiums are not subject to repartition between the NFZ's branches, therefore, this eliminates a possibility of mutual incomes and expenses $^{31}$. A health insurance premium (target tax) is important as far as its fiscal, redistribution and allocation aspects are concerned. A fiscal function is certainly of an essential importance since efficiency in this scope depends on a tax capacity of households (directly) and entrepreneurs (indirectly) as well as the structure of a health insurance premium. J. Sobiech indicates that a fiscal capacity of a health insurance premium depends on the total financial burden as well as the taxation structure and the condition of the economy (including public finance) ${ }^{32}$. It is difficult to talk about redistribution importance when only the National Health Fund is authorized to collect premiums and the system lacks private insurers that could use the premium. The allocation function is imbalanced too because a relation between the premium and service does not exist in the present system.

The reforms carried out so far have still failed to decide about a crucial issue for the health protection system functioning. There are no clear criteria dividing services into basic ones, financed by public resources (from health insurances) and secondary ones (financed from private resources). 


\section{Streszczenie}

W rezultacie reform przeprowadzonych w minionej dekadzie, w Polsce funkcjonuje mieszany model finansowania usług medycznych. $Z$ jednej strony występuje model, w których środki finansowe pochodzą ze składek osób ubezpieczonych lub $\mathrm{z}$ budżetu państwa, $\mathrm{z}$ drugiej - również $\mathrm{z}$ budżetu państwa finansowana jest określona grupa świadczeń (świadczenia wysokospecjalistyczne). Od 1999 r. finansowanie systemu opieki zdrowotnej opiera się na kilku źródłach. Największym z nich są składki na ubezpieczenie zdrowotne gromadzone w Narodowym Funduszu Ochrony Zdrowia; następnie środki publiczne pochodzące z budżetu państwa i w dalszej kolejności z budżetów jednostek samorządu terytorialnego, kończąc na pozabudżetowych funduszach celowych oraz w najmniejszym zakresie - środki organizacji społecznych, m.in. fundacji działających w tym zakresie. Ponadto ważną rolę w finansowaniu ochrony zdrowia ze środków prywatnych stanowią zasoby gospodarstw domowych, specjalistyczne fundusze tworzone w zakładach pracy oraz organizacje charytatywne. Generalnie finansowanie jest kluczowym zagadnieniem reformy opieki zdrowotnej wobec pozostałych problemów. 